\title{
Karakterisasi Morfologi dan Pertumbuhan Populasi Planlet Anggrek Phalaenopsis Hasil Persilangan Selama Tahap Aklimatisasi
}

\author{
Morphological Characterization and Population Growth of Phalaenopsis Orchid Plantlets \\ Crosses in Acclimatization Phase
}

Tya Wulandari $^{1}$ dan Dewi Sukma ${ }^{*}$

Diterima 12 Agustus 2014/Disetujui 29 Oktober 2014

\begin{abstract}
This research was conducted at the Orchids House, KP. Leuwikopo, Bogor, Indonesia from December 2013 until May 2014. The objectives of research were to study the morphological characterization and the effect of some types of leaf fertilizer on the growth of hybrid Phalaenopsis plantlets. The research consisted of 2 experiments, the first one was morphological characterization and the second was population growth of orchid plantlets. Morphological characterization was conducted according to Balithi guidance for Phalaenopsis characteristic (Balithi, 2007). The morphological data was analysed by using NTSYSpc 2.02 version, presented in the form of a dendrogram. The population growth experiment used a Completely Randomized Factorial Design consisted of two factors, namely population and leaf fertilizers. The results of data analysis in morphological characterization showed that individuals in the each population has different number of similarity coefficients, D015 (59\%), A001 (80\%), D022 (78\%), P4 (76\%), and TSW-1103 (63\%). In the second experiment showed that fertilizer treatments supertonik $3 \mathrm{ml} L^{-1}+3$ ppm chitosan significantly affected the number of leaves in the population TSW-1111 (Phalaenopsis Timothy Christopher x Phalaenopsis Leopard Prince) of $4.60 \pm 0.70$ at 12 Weeks After Treatment (WAT).
\end{abstract}

Keywords: acclimatization, growth of plantlet, morphological characterization

\begin{abstract}
ABSTRAK
Penelitian dilaksanakan di Rumah Anggrek, KP. Leuwikopo, Bogor, Indonesia pada bulan Desember 2013 hingga Mei 2014. Penelitian ini dilakukan untuk mempelajari karakterisasi morfologi dan pengaruh pemberian beberapa jenis pupuk daun terhadap pertumbuhan planlet anggrek Phalaenopsis hasil persilangan. Penelitian terdiri atas 2 percobaan, yaitu karakterisasi morfologi dan pertumbuhan populasi planlet anggrek. Karakterisasi morfologi dilakukan berdasarkan panduan karakterisasi anggrek Phalaenopsis (Balithi, 2007). Percobaan karakterisasi morfologi diolah menggunakan program NTSYSpc versi 2.02 yang disajikan dalam bentuk dendogram. Percobaan pertumbuhan populasi menggunakan rancangan acak lengkap faktorial yang terdiri atas 2 faktor, yaitu populasi dan pupuk daun. Hasil analisis data pada percobaan karakterisasi morfologi menunjukkan bahwa individu dalam setiap populasi memiliki koefisien kemiripan yang berbeda, D015 (59\%), A001 (80\%), D022 (78\%), P4 (76\%), and TSW-1103 (63\%). Percobaan ke-2 menunjukkan bahwa perlakuan pupuk supertonik $3 \mathrm{ml} \mathrm{L}^{-1}+$ chitosan $3 \mathrm{ppm}$ berpengaruh nyata terhadap pertambahan jumlah daun pada populasi TSW-1111 (Phalaenopsis Timothy Christopher $\mathrm{x}$ Phalaenopsis Leopard Prince) sebesar 4.60 \pm 0.70 helai saat 12 MSP.
\end{abstract}

Kata kunci: aklimatisasi, karakterisasi morfologi, pertumbuhan planlet

\footnotetext{
${ }^{1}$ Departemen Agronomi dan Hortikultura, Fakultas Pertanian, Institut Pertanian Bogor

(Bogor Agricultural University), Jl. Meranti, Kampus IPB Darmaga, Bogor 16680, Indonesia

Telp.\&Faks.62-251-8629353. *E-mail korespondensi: dsukma70@yahoo.com
} 


\section{PENDAHULUAN}

Anggrek merupakan salah satu komoditas tanaman hias yang banyak diminati oleh berbagai kalangan di Indonesia. Komoditas ini merupakan salah satu kekayaan hayati yang sangat potensial untuk dikembangkan pemasarannya dalam sub sektor bisnis hortikultura. Lebih dari 5000 spesies dari famili ini dapat ditemukan di Indonesia. Phalaenopsis atau yang lebih dikenal sebagai anggrek bulan adalah salah satu tanaman anggrek yang banyak diminati karena keindahan bentuk dan warna bunganya. Dibandingkan dengan produktivitas anggrek dari negara tetangga, seperti Thailand dengan rata-rata 10-12 tangkai per tanaman, maka produktivitas anggrek Indonesia secara nasional rata-rata sangat kecil, yaitu hanya dapat mencapai 3-4 tangkai per tanaman (Direktorat Tanaman Hias, 2004). Banyaknya permintaan pasar terhadap anggrek Phalaenopsis tidak diimbangi dengan ketersediaan bibit yang memadai. Hal ini dapat diatasi melalui suatu metode terbaik hingga saat ini dalam melestarikan dan memperbanyak anggrek, yaitu melalui metode kultur jaringan (BPPT, 2008).

Salah satu tahapan terpenting dalam perbanyakan tanaman secara in vitro adalah aklimatisasi yang akan menentukan keberhasilan tumbuh planlet di lingkungan ex vitro (Arditi, 1997). Aklimatisasi adalah proses adaptasi suatu planlet terhadap perubahan dari lingkungan heterotrof ke lingkungan autotrof (Kartikasari, 2009). Tahapan ini dilakukan agar tanaman yang sebelumnya ditumbuhkan dalam botol kultur dengan suplai media lengkap tetap dapat bertahan hidup secara mandiri dan berfotosintesis pada kondisi lingkungan eksternal (Yosepa et al., 2012). Spaghnum moss merupakan jenis lumut-lumutan yang memiliki sistem drainase yang baik sehingga dapat dijadikan sebagai media tanam untuk pertumbuhan planlet anggrek Phalaenopsis (Suryati, 2007). Selain media tanam, salah satu faktor yang penting diperhatikan dalam tahap aklimatisasi adalah pemupukan. Pemberian pupuk pada tanaman anggrek mengutamakan tiga unsur hara yang diperlukan, yaitu unsur nitrogen $(\mathrm{N})$, fosfor $(\mathrm{P})$, dan kalium $(\mathrm{K})$. Unsur $\mathrm{N}$ berpengaruh dalam meningkatkan pertumbuhan vegetatif, unsur $\mathrm{P}$ untuk merangsang pertumbuhan generatif, inisiasi akar, dan pendewasaan tanaman, dan unsur $\mathrm{K}$ sebagai katalisator (Ginting et al., 2001). Dalam bidang pertanian, chitosan menawarkan alternatif alami dalam penggunaan bahan kimia yang terkadang berbahaya bagi lingkungan dan manusia. Chitosan membuat mekanisme pertahanan pada tumbuhan, menstimulasi pertumbuhan, dan merangsang enzim tertentu. Pengontrol organik baru ini menawarkan pendekatan sebagai alat biokontrol (Zhao, 2005).

Populasi planlet hasil persilangan antara varietas hibrida memiliki karakter morfologi dan kecepatan pertumbuhan yang berbedabeda. Karakterisasi morfologi diperlukan untuk melihat keragaman morfologi planlet dalam populasi. Respon pertumbuhan planlet dalam suatu populasi belum tentu sama dengan populasi yang lainnya. Respon fenotipe tanaman merupakan interaksi antara genotipe dengan lingkungan (Syukur et al., 2012). Penelitian ini bertujuan untuk mempelajari karakterisasi morfologi dan pengaruh pemberian beberapa jenis pupuk daun terhadap pertumbuhan planlet anggrek Phalaenopsis hasil persilangan.

\section{BAHAN DAN METODE}

Penelitian ini dilaksanakan di screen house Rumah Anggrek, Kebun Percobaan Leuwikopo, Departemen Agronomi dan Hortikultura, Fakultas Pertanian, Institut Pertanian Bogor. Penelitian berlangsung mulai Desember 2013 hingga Mei 2014. Penelitian terdiri atas dua percobaan, yaitu :

\section{Percobaan 1. Karakterisasi Morfologi Populasi Planlet Anggrek Phalaenopsis Hasil Selfing/Persilangan}

Rancangan lingkungan yang akan digunakan adalah rancangan acak lengkap (RAL) satu faktor (Gomez dan Gomez, 1995), yaitu 5 populasi anggrek hasil silangan dan selfing. Percobaan 1 dilakukan ketika planlet anggrek berumur 16 MST (minggu setelah tanam) kemudian pemeliharaan berupa pemupukan secara periodik tanpa adanya perlakuan. Populasi yang digunakan adalah populasi P4 (Phalaenopsis amabilis borneo 1), D015 (Phalaenopsis standar putih $x$ Phalaenopsis standar pink), TSW-1103 (Phalaenopsis sogo diamond $x$ Phalaenopsis jinbao red 
rose), A001 dan D022 (Phalaenopsis standar pink $x$ Phalaenopsis standar putih). Populasi planlet hasil selfing adalah populasi $\mathrm{P} 4$, sedangkan populasi planlet hasil persilangan adalah populasi TSW-1103, A001, D015, dan D022. Setiap populasi terdiri atas sekurangkurangnya 10 planlet sehingga terdapat minimal 60 planlet yang ditanam. Pengamatan terdiri atas karakter kualitatif dan kuantitatif. Karakter kualitatif dan kuantitatif akan diubah (skoring) ke dalam bentuk data biner. Data biner digunakan untuk menganalisis keragaman genetik menggunakan program numerical taxonomy and multivariate analysis system (NTSYSpc) versi 2.02 (Rohlf, 1998).

Karakter kualitatif yang diamati meliputi: warna pinggir daun, warna permukaan atas daun, warna permukaan bawah daun, bentuk daun, dan warna ujung akar. Skoring dilakukan pada karakter warna pinggir daun, warna permukaan atas daun, warna permukaan bawah daun menjadi warna hijau, keunguan, dan hijau keunguan. Karakter yang memunculkan warna tersebut diberi nilai 1 , sedangkan yang lainnya diberi nilai 0 . Bentuk daun dibedakan menjadi bulat, lanset, dan semi lanset, sedangkan warna ujung akar dibedakan menjadi 2, yaitu hijau dan kuning kemudian sistem pemberian skoring adalah sama seperti yang dilakukan sebelumnya. Hasil analisis data akan disajikan dalam bentuk dendogram. Karakter kuantitatif yang diamati meliputi: 1) Panjang daun (cm), 2) Lebar daun (cm), 3) Rasio panjang daun dibandingkan dengan lebar daun (tidak bersatuan), 4) Jumlah daun (helai), 5) Panjang akar (cm), 6) Jumlah akar (helai), dan 7) Persentase tumbuh (\%).

\section{Percobaan 2. Respon Pertumbuhan Populasi Planlet Anggrek Phalaenopsis Hasil Persilangan Pada Berbagai Perlakuan Pupuk Daun}

Percobaan ini disusun menggunakan rancangan acak lengkap (RAL) faktorial dengan dua faktor perlakuan, yaitu pupuk daun dan populasi sehingga terdapat 12 kombinasi perlakuan (4 taraf pemupukan x 3 populasi). Percobaan 2 dilakukan ketika planlet anggrek berumur 8 MST dengan adanya perlakuan yang diberikan terhadap tanaman. Perlakuan pupuk daun terdiri atas empat taraf, yaitu Q1 = pupuk supertonik $3 \mathrm{ml} \mathrm{L}^{-1}$; $\mathrm{Q} 2=$ pupuk pertumbuhan $1.25 \mathrm{~g} \mathrm{~L}^{-1}$; $\mathrm{Q} 3$ = pupuk super- tonik $3 \mathrm{ml} \mathrm{L}^{-1}+$ chitosan $3 \mathrm{ppm}$; dan $\mathrm{Q} 4=$ pupuk pertumbuhan $1.25 \mathrm{~g} \mathrm{~L}^{-1}+$ chitosan 3 ppm. Populasi planlet anggrek yang digunakan terdiri atas tiga populasi, yaitu P1 = TSW-1107 (Phalaenopsis Taipei Gold $\mathrm{x}$ Phalaenopsis venosa), $\mathrm{P} 2=\mathrm{TSW}-1111$ (Phalaenopsis Timothy Christopher x Phalaenopsis Leopard Prince), dan P3 = TSW-1113 (Phalaenopsis Shin Spotted Deer Siblings Cross). Setiap kombinasi perlakuan terdiri atas tiga ulangan, masing-masing ulangan terdiri atas 5 planlet sehingga jumlah planlet yang ditanam adalah 180 planlet. Setiap kombinasi perlakuan terdapat lima planlet yang akan diamati sehingga terdapat 180 planlet sebagai satuan amatan.

Pengamatan dilakukan pada karakter kualitatif dan kuantitatif. Karakter kualitatif dan kuantitatif yang diamati sama seperti percobaan 1. Data kualitatif pada percobaan 2 akan disajikan dalam tabel setelah dicari modusnya, sedangkan data kuantitatif akan diolah dengan uji $\mathrm{F}$ pada sistem SAS (Statistical Analysis System) kemudian dilakukan uji lanjut DMRT (Duncan Multiple Range Test) pada perlakuan yang berpengaruh nyata pada taraf $5 \%$.

\section{HASIL DAN PEMBAHASAN}

\section{Kondisi Umum Penelitian}

Selama tahap aklimatisasi, planlet anggrek pada percobaan 2 menunjukkan penampilan visual yang cukup baik hingga 8 MSP, begitu pula pada percobaan 1 menunjukkan hasil yang cukup baik hingga penelitian selesai dilaksanakan. Selama pertumbuhan vegetatif, tanaman memerlukan unsur hara yang ditranslokasikan ke seluruh bagian tubuh tanaman. Salah satu unsur hara yang diberikan, yaitu pupuk. Menurut Ginting et al. (2001), unsur $\mathrm{N}$ berpengaruh dalam meningkatkan pertumbuhan vegetatif tanaman. Planlet anggrek pada percobaan 2 yang diberikan perlakuan pupuk daun memberikan respon tumbuh yang berbeda. Beberapa planlet anggrek mati disebabkan adanya penyakit busuk basah Erwinia sp., daun mengalami kekeringan karena sun burn, dan pemberian konsentrasi pupuk pertumbuhan yang terlalu tinggi. Faktor lain yang dapat menyebabkan terjadinya kondisi tersebut, antara lain media tanam, intensitas pemupukan, dan faktor iklim 
mikro di sekitar lingkungan penanaman (Wiyono, 2007). Kondisi media tanam berupa spaghnum moss terlalu lembab. Hal ini berkaitan dengan intensitas pemupukan yang awalnya dilakukan dua hari sekali saat curah hujan cukup tinggi di daerah penanaman. Selain itu, volume penyiraman yang kurang terkontrol dengan baik dan perlu disesuaikan dengan kelembaban media.

\section{Percobaan 1. Karakterisasi Morfologi Populasi Planlet Anggrek Phalaenopsis Hasil Selfing/Persilangan}

Populasi planlet anggrek Phalaenopsis yang diamati dalam percobaan 1 adalah D015, A001，D022， P4, dan TSW-1103. Hasil karakterisasi morfologi dari setiap populasi disajikan dalam bentuk dendogram. Populasi D015 memiliki koefisien kemiripan 59\% dengan setiap individu mengelompok sesuai dengan kemiripan karakter yang diamati (Gambar 1a). Koefisien kemiripan pada setiap individu, yaitu individu 1 (66\%), individu 8,3 , 6, $9(80 \%)$ dimana individu 3 dan 6 memiliki kemiripan yang sama persis, individu 4 $(80.5 \%)$, individu $2(87.5 \%)$, dan individu 5 dan 7 (96\%). Populasi A001 memiliki koefisien kemiripan sebesar $80 \%$ dengan nilai yang berbeda pada setiap kelompok individunya, yaitu individu $4(81.5 \%)$, individu $2(91.5 \%)$, individu 3 dan 6 (94.5\%), dan individu 1, 5, 7 (95.5\%) dengan individu 5 dan 7 adalah individu yang sangat mirip (Gambar 1b). Berdasarkan gambar 1c, populasi D022 dengan koefisien kemiripan sebesar $78 \%$ terdiri atas individu-individu yang mengelompok dengan koefisien kemiripan yang berbeda, yaitu kelompok koefisien kemiripan $84.5 \%$ terdiri atas individu $8(92 \%)$, individu $4(93.5 \%)$, individu 5, 10, 9 (95\%) dengan individu 5 dan 10 sangat mirip, serta individu 2 dan 6 (95.5\%), sedangkan individu 3 memiliki koefisien kemiripan $87 \%$ serta individu 1 dan 7 (94.5\%). P4 yang merupakan populasi hasil selfing memiliki koefisien kemiripan sebesar $76 \%$ dengan individu yang tidak begitu beragam (Gambar 1d). Individu 1 memiliki koefisien kemiripan sebesar $81.5 \%$, individu 2 , $3,5,6,7,8,9(95.5 \%)$ dengan individu yang sangat mirip $(3,5,6,7,8,9)$, sedangkan individu 4 memiliki koefisien kemiripan sebesar $76 \%$. Berdasarkan gambar 1e, populasi TSW-1103 memiliki koefisien kemiripan 63\% terdiri atas individu 6 (74\%), individu 5 (87\%), individu 4 (92.5\%), individu 7 dan 8 (93\%), dan pada koefisien kemiripan $94.5 \%$ terdapat individu 1, 3, 2 dimana individu 1 dan 3 adalah individu yang sangat mirip.

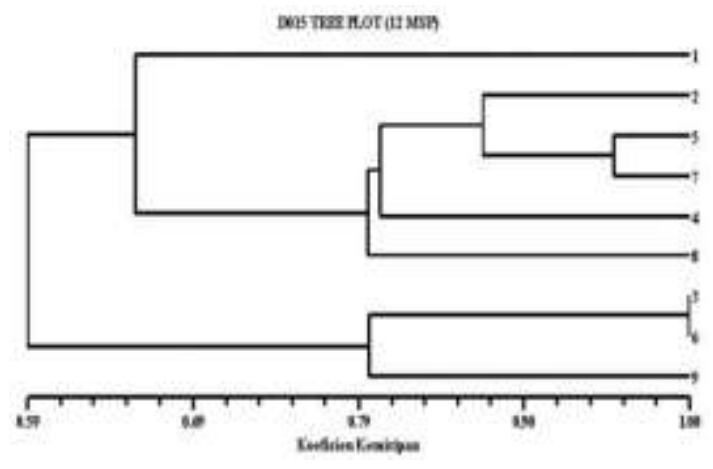

Gambar 1a. Kemiripan individu dalam populasi D015 saat 12 MSP.

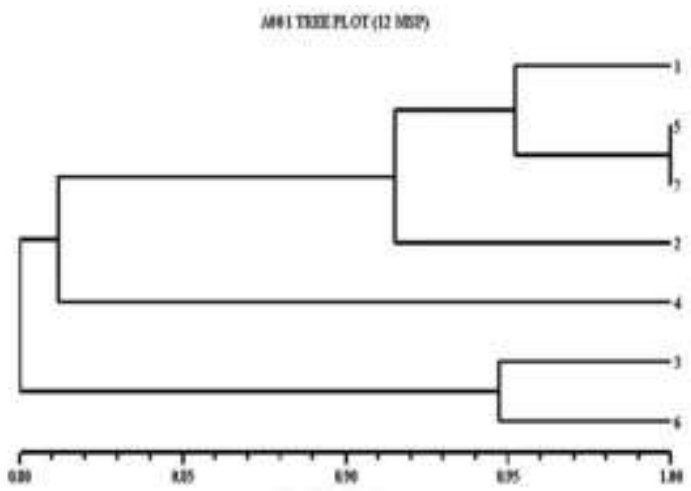

Gambar 1b. Kemiripan individu dalam populasi A001 saat 12 MSP.

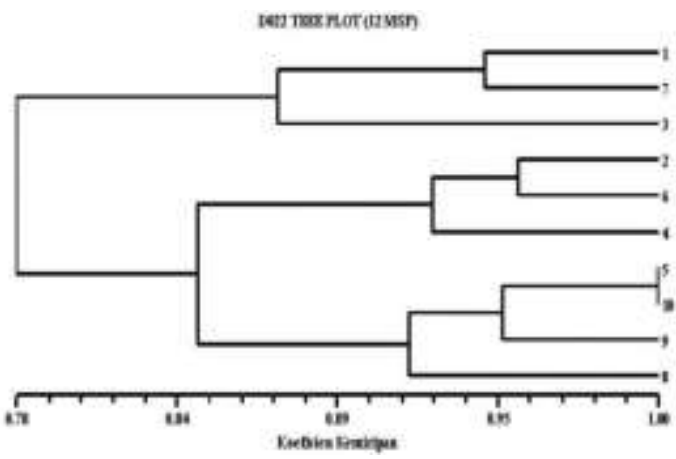

Gambar 1c. Kemiripan individu dalam populasi D022 saat 12 MSP. 


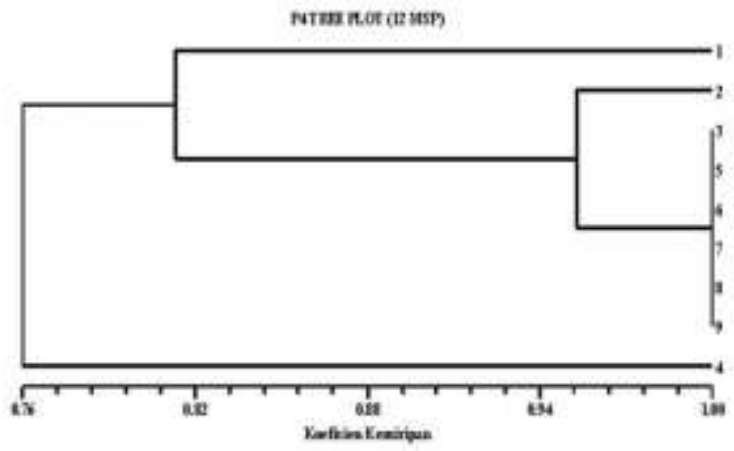

Gambar 1d. Kemiripan individu dalam populasi P4 saat $12 \mathrm{MSP}$

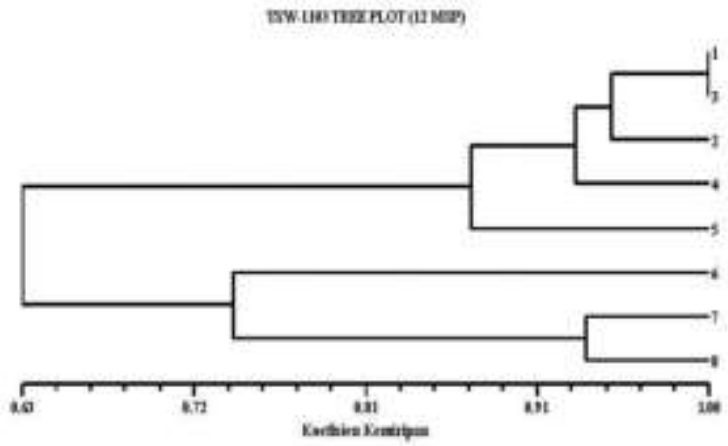

Gambar 1e. Kemiripan individu dalam populasi TSW-1103 saat 12 MSP
Percobaan 2. Respon pertumbuhan populasi planlet anggrek Phalaenopsis hasil persilangan pada berbagai perlakuan pupuk daun

\section{Persentase Tumbuh}

Planlet anggrek 100\% hidup hingga umur 4 MSP, saat berumur 8 MSP pada perlakuan populasi TSW-1111 dan TSW-1113 persentase hidup tanaman turun menjadi 98.33\%. Perlakuan pupuk menunjukkan persentase hidup mulai berkurang saat berumur 8 MSP pada perlakuan pupuk pertumbuhan $1.25 \mathrm{~g} \quad \mathrm{~L}^{-1}$ dan pupuk pertumbuhan $1.25 \mathrm{~g} \mathrm{~L}^{-1}+$ chitosan $3 \mathrm{ppm}$ sebesar $97.78 \%$.

Persentase hidup planlet anggrek terus berkurang hingga umur 16 MSP. Saat berumur 16 MSP perlakuan populasi memberikan hasil yang berpengaruh nyata terhadap persentase tumbuh tanaman. Populasi TSW-1111 $(61.67 \%)$ menunjukkan hasil yang berbeda nyata dengan kedua populasi lainnya, sedangkan pada perlakuan pupuk menunjukkan bahwa penggunaan pupuk supertonik $3 \mathrm{ml} \mathrm{L}^{-1}$ + chitosan 3 ppm (86.68\%) dan pupuk supertonik $3 \mathrm{ml} \mathrm{L} \mathrm{L}^{-1}$ (77.78\%) memberikan hasil yang berbeda nyata dengan kedua pupuk lainnya (Tabel 1).

Tabel 1. Rata-rata persentase tumbuh planlet anggrek Phalaenopsis tahap aklimatisasi

\begin{tabular}{|c|c|c|c|c|c|}
\hline \multirow{2}{*}{ Perlakuan } & \multicolumn{4}{|c|}{ Umur Planlet (MSP) } & \multirow[b]{2}{*}{16} \\
\hline & 0 & 4 & 8 & 12 & \\
\hline & \multicolumn{5}{|c|}{ Persentase Tumbuh (\%). } \\
\hline \multicolumn{6}{|l|}{ Populasi (P) } \\
\hline TSW-1107 & 100 & 100 & 100 & 88.3 & $55.0 \mathrm{ab}$ \\
\hline TSW-1111 & 100 & 100 & 98.3 & 78.3 & $61.7 \mathrm{a}$ \\
\hline TSW-1113 & 100 & 100 & 98.3 & 80.0 & $38.3 b$ \\
\hline $\operatorname{Pr}>\mathrm{F}$ & . & . & $0.61^{\mathrm{tn}}$ & $0.42^{\mathrm{tn}}$ & $0.03^{*}$ \\
\hline \multicolumn{6}{|l|}{ Pupuk Daun (Q) } \\
\hline Supertonik $3 \mathrm{ml} \mathrm{L}^{-1}$ & 100 & 100 & 100 & $91.1 \mathrm{a}$ & $77.8 \mathrm{a}$ \\
\hline Pertumbuhan $1.25 \mathrm{~g} \mathrm{~L}^{-1}$ & 100 & 100 & 97.8 & $80.0 \mathrm{a}$ & $31.1 \mathrm{~b}$ \\
\hline Supertonik $3 \mathrm{ml} \mathrm{L}^{-1}+$ chitosan $3 \mathrm{ppm}$ & 100 & 100 & 100 & $97.8 \mathrm{a}$ & $86.7 \mathrm{a}$ \\
\hline Pertumbuhan $1.25 \mathrm{~g} \mathrm{~L}^{-1}+$ chitosan $3 \mathrm{ppm}$ & 100 & 100 & 97.8 & $60.0 \mathrm{~b}$ & $11.1 \mathrm{~b}$ \\
\hline $\operatorname{Pr}>\mathrm{F}$ & . & . & $0.5807^{\mathrm{tn}}$ & $0.0026^{* *}$ & $<.0001^{* *}$ \\
\hline Interaksi PxQ & . & . & $1.2^{\mathrm{tn}}$ & $2.41^{\mathrm{tn}}$ & $0.30^{\mathrm{tn}}$ \\
\hline $\mathrm{KK}(\%)$ & 0.00 & 0.00 & 4.77 & 23.98 & 40.80 \\
\hline
\end{tabular}


Pemupukan dengan kedua jenis pupuk yang berbeda dan adanya kombinasi perlakuan pupuk dengan chitosan memberikan respon yang berbeda terhadap kondisi planlet anggrek selama perlakuan. Penggunaan pupuk supertonik lebih baik digunakan pada kondisi planlet anggrek yang masih berumur muda, sedangkan kemungkinan penggunaan pupuk pertumbuhan lebih cocok digunakan pada bibit anggrek yang telah dewasa. Planlet anggrek yang masih berumur muda atau belum siap diaklimatisasi dapat menolak respon pemupukan yang diberikan. Pupuk pertumbuhan yang diberikan kemungkinan terlalu tinggi konsentrasinya untuk ukuran planlet yang masih kecil. Persentase tumbuh tanaman juga dipengaruhi oleh kondisi akar tanaman yang mengalami kerusakan akibat terjadi pembusukan akar sehingga fungsi akar berkurang.

\section{Jumlah Daun}

Jumlah daun yang diamati setiap bulan setelah perlakuan menunjukkan hasil yang tidak berpengaruh nyata (Tabel 2). Penambahan jumlah daun planlet anggrek selama tahap aklimatisasi bersifat fluktuatif karena adanya pergantian fase antara daun muda yang baru tumbuh dan daun dewasa yang mati selama berlangsungnya pengamatan. Pertumbuhan daun anggrek pada rumpun pertumbuhan pertama sangat minim karena proses aklimatisasi pada tanaman merupakan tahap adaptasi tanaman terhadap cekaman iklim yang berbeda (Suradinata et al., 2012). Hasil interaksi yang nyata antara perlakuan populasi dan pupuk daun saat 12 MSP terlihat pada Tabel 3. Interaksi antara populasi TSW1113 dan perlakuan pupuk pertumbuhan 1.25 $\mathrm{g} \mathrm{L}^{-1}+$ chitosan $3 \mathrm{ppm}(5.0 \pm 0.9$ helai) serta populasi TSW-1111 dan perlakuan pupuk supertonik $3 \mathrm{ml} \mathrm{L}^{-1}+$ chitosan $3 \mathrm{ppm}(4.6 \pm 0.7$ helai) terhadap pengamatan jumlah daun saat 12 MSP menunjukkan hasil yang lebih tinggi dibandingkan interaksi lainnya.

Tabel 2. Rata-rata jumlah daun planlet anggrek Phalaenopsis selama tahap aklimatisasi

\begin{tabular}{|c|c|c|c|c|}
\hline \multirow{2}{*}{ Perlakuan } & \multicolumn{4}{|c|}{ Umur Planlet (MSP) } \\
\hline & 0 & 4 & 8 & 12 \\
\hline & \multicolumn{4}{|c|}{.........Jumlah Daun (Helai).......... } \\
\hline \multicolumn{5}{|l|}{ Populasi (P) } \\
\hline TSW-1107 & 3.37 & 3.57 & 4.00 & 4.03 \\
\hline TSW-1111 & 3.37 & 3.90 & 4.33 & 4.30 \\
\hline TSW-1113 & 3.57 & 3.88 & 4.28 & 4.33 \\
\hline $\operatorname{Pr}>\mathrm{F}$ & $0.3069^{\operatorname{tn}}$ & $0.1832^{\operatorname{tn}}$ & $0.2175^{\text {tn }}$ & $0.1958^{\mathrm{tn}}$ \\
\hline \multicolumn{5}{|l|}{ Pupuk Daun (Q) } \\
\hline Supertonik $3 \mathrm{ml} \mathrm{L}^{-1}$ & $3.51 \mathrm{ab}$ & 3.62 & 4.17 & 4.27 \\
\hline Pertumbuhan $1.25 \mathrm{~g} \mathrm{~L}^{-1}$ & $3.20 \mathrm{~b}$ & 3.69 & 4.09 & 4.08 \\
\hline Supertonik $3 \mathrm{ml} \mathrm{L}^{-1}+$ chitosan $3 \mathrm{ppm}$ & $3.33 \mathrm{ab}$ & 3.84 & 4.13 & 4.32 \\
\hline Pertumbuhan $1.25 \mathrm{~g} \mathrm{~L}^{-1}+$ chitosan $3 \mathrm{ppm}$ & $3.69 \mathrm{a}$ & 3.98 & 4.42 & 4.20 \\
\hline $\operatorname{Pr}>F$ & $0.0430^{*}$ & $0.4154^{\operatorname{tn}}$ & $0.4887^{\text {tn }}$ & $0.6830^{\mathrm{tn}}$ \\
\hline Interaksi PxQ & $0.99^{\operatorname{tn}}$ & $0.55^{\mathrm{tn}}$ & $0.65^{\text {tn }}$ & $3.19^{*}$ \\
\hline KK (\%) & 10.46 & 12.74 & 11.46 & 10.17 \\
\hline
\end{tabular}

Keterangan : *: berpengaruh nyata pada taraf 5\%; **: berpengaruh sangat nyata pada taraf $1 \%$; tn: tidak berpengaruh nyata; $\operatorname{Pr}$ Probability; KK: Koefisien keragaman. Angka-angka yang diikuti huruf yang sama pada kolom yang sama menunjukkan hasil yang tidak berbeda nyata berdasarkan uji DMRT pada taraf 5\%; MSP: minggu setelah perlakuan. 
Tabel 3. Interaksi antara perlakuan populasi dan pupuk daun planlet anggrek Phalaenopsis pada umur $12 \mathrm{MSP}$

\begin{tabular}{|c|c|c|c|}
\hline \multirow{2}{*}{ Perlakuan } & \multicolumn{3}{|c|}{ Populasi (P) } \\
\hline & TSW-1107 & TSW-1111 & TSW-1113 \\
\hline & \multicolumn{3}{|c|}{............Jumlah Daun (Helai) .............. } \\
\hline \multicolumn{4}{|l|}{ Pupuk Daun (Q) } \\
\hline Supertonik $3 \mathrm{ml} \mathrm{L}^{-1}$ & $4.3 \pm 0.2$ & $4.6 \pm 0.2$ & $3.9 \pm 0.6$ \\
\hline Pertumbuhan $1.25 \mathrm{~g} \mathrm{~L}^{-1}$ & $3.9 \pm 0.4$ & $4.2 \pm 0.2$ & $4.0 \pm 0.3$ \\
\hline Supertonik $3 \mathrm{ml} \mathrm{L}^{-1}+$ chitosan $3 \mathrm{ppm}$ & $4.0 \pm 0.3$ & $4.6 \pm 0.7$ & $4.3 \pm 0.1$ \\
\hline Pertumbuhan $1.25 \mathrm{~g} \mathrm{~L}^{-1}+$ chitosan $3 \mathrm{ppm}$ & $3.8 \pm 0.2$ & $3.8 \pm 0.2$ & $5.0 \pm 0.9$ \\
\hline
\end{tabular}

\section{Panjang Daun}

Panjang daun untuk setiap populasi mengalami peningkatan setiap minggunya hingga 12 MSP. Perlakuan populasi berpengaruh sangat nyata terhadap panjang daun. Populasi TSW-1111 menunjukkan panjang daun yang lebih rendah dibandingkan kedua populasi lainnya. Secara berturut-turut mulai dari 0 MSP hingga 12, yaitu 2.25, 2.28, 2.20, dan $2.68 \mathrm{~cm}$ (Tabel 4). Perlakuan pupuk menunjukkan hasil yang berpengaruh nyata terhadap panjang daun saat 12 MSP. Penambahan panjang, lebar daun, dan jumlah daun merupakan suatu tanda tanaman melakukan pertumbuhan vegetatif. Pertumbuhan vegetatif sangat dipengaruhi oleh unsur $\mathrm{N}$ karena unsur tersebut dapat memperbaiki pertumbuhan vegetatif suatu tanaman (Hardjowigeno, 2007).

Tabel 4. Rata-rata panjang daun planlet anggrek Phalaenopsis selama tahap aklimatisasi

\begin{tabular}{|c|c|c|c|c|}
\hline \multirow{2}{*}{ Perlakuan } & \multicolumn{4}{|c|}{ Umur Planlet (MSP) } \\
\hline & 0 & 4 & 8 & 12 \\
\hline & \multicolumn{4}{|c|}{$\ldots \ldots \ldots \ldots \ldots \ldots \ldots$ Panjang Daun $(\mathrm{cm}) \ldots \ldots \ldots \ldots \ldots \ldots \ldots$} \\
\hline \multicolumn{5}{|l|}{ Populasi (P) } \\
\hline TSW-1107 & $2.96 \mathrm{a}$ & $3.19 \mathrm{a}$ & $2.97 \mathrm{a}$ & $3.34 \mathrm{a}$ \\
\hline TSW-1111 & $2.25 b$ & $2.28 \mathrm{~b}$ & $2.20 \mathrm{~b}$ & $2.68 b$ \\
\hline TSW-1113 & $3.24 \mathrm{a}$ & $3.11 \mathrm{a}$ & $2.91 \mathrm{a}$ & $3.28 \mathrm{a}$ \\
\hline $\operatorname{Pr}>\mathrm{F}$ & $<.0001^{* *}$ & $<.0001^{* *}$ & $0.0005^{* *}$ & $0.0045^{* * *}$ \\
\hline \multicolumn{5}{|l|}{ Pupuk Daun (Q) } \\
\hline Supertonik $3 \mathrm{ml} \mathrm{L}^{-1}$ & 3.11 & 3.13 & 2.94 & $3.44 \mathrm{a}$ \\
\hline Pertumbuhan $1.25 \mathrm{~g} \mathrm{~L}^{-1}$ & 2.77 & 2.86 & 2.63 & $3.01 \mathrm{ab}$ \\
\hline Supertonik $3 \mathrm{ml} \mathrm{L}^{-1}+$ chitosan $3 \mathrm{ppm}$ & 2.81 & 2.85 & 2.83 & $3.20 \mathrm{ab}$ \\
\hline Pertumbuhan $1.25 \mathrm{~g} \mathrm{~L}^{-1}+$ chitosan $3 \mathrm{ppm}$ & 2.59 & 2.59 & 2.37 & $2.74 \mathrm{~b}$ \\
\hline $\operatorname{Pr}>\mathrm{F}$ & $0.1413^{\text {tn }}$ & $0.1300^{\operatorname{tn}}$ & $0.0685^{\text {tn }}$ & $0.0358^{*}$ \\
\hline Interaksi PxQ & $1.20^{\operatorname{tn}}$ & $1.11^{\text {tn }}$ & $1.75^{\text {tn }}$ & $1.45^{\text {tn }}$ \\
\hline $\mathrm{KK}(\%)$ & 16.24 & 15.99 & 17.15 & 15.70 \\
\hline
\end{tabular}

Keterangan : *: berpengaruh nyata pada taraf 5\%; **: berpengaruh sangat nyata pada taraf 1\%; tn: tidak berpengaruh nyata; Pr: Probability; KK: Koefisien keragaman. Angka-angka yang diikuti huruf yang sama pada kolom yang sama menunjukkan hasil yang tidak berbeda nyata berdasarkan uji DMRT pada taraf 5\%; MSP: minggu setelah perlakuan. 


\section{Lebar Daun}

Perlakuan populasi menunjukkan hasil yang berpengaruh sangat nyata setiap minggunya (Tabel 5). Populasi TSW-1107 berbeda nyata dengan populasi lainnya, secara berturut mulai dari 0 MSP hingga 12 , yaitu $1.31,1.24,1.27$, dan $1.21 \mathrm{~cm}$. Pada perlakuan pupuk menunjukkan hasil yang berpengaruh nyata pada 0 dan 12 MSP. Perlakuan pupuk supertonik $3 \mathrm{ml} \mathrm{L}^{-1}(1.63 \mathrm{~cm})$ saat $12 \mathrm{MSP}$ hasilnya berbeda nyata dengan perlakuan pupuk pertumbuhan $1.25 \mathrm{~g} \mathrm{~L}^{-1}+$ chitosan 3 ppm $(1.28 \mathrm{~cm})$. Menurut Suwandi dan Chan (1982), unsur $\mathrm{P}, \mathrm{K}, \mathrm{Mg}, \mathrm{Ca}$, dan $\mathrm{S}$ berperan dalam menunjang pertumbuhan lebar daun. Penyerapan unsur hara melalui permukaan daun yang diberikan secara optimal akan merespon pertumbuhan vegetatif tanaman, termasuk pelebaran daun (Iswanto, 2005). Menurut Surtinah dan Mutryarny (2013), pemberian pupuk 3 hari sekali dapat memacu pertumbuhan tunas, memperlebar daun, dan memperpanjang daun anggrek Dendrobium. Hal ini menunjukkan bahwa zat hara yang terkandung di dalam pupuk dapat dimanfaatkan oleh bibit untuk proses pertumbuhannya.

\section{Jumlah Akar}

Perlakuan terhadap ketiga populasi tidak memberikan pengaruh yang nyata terhadap jumlah akar. Hasil analisis statistik terhadap jumlah akar berpengaruh nyata pada perlakuan pupuk daun saat planlet anggrek berumur 12 MSP. Berdasarkan Tabel 6, perlakuan pupuk supertonik $3 \mathrm{ml} \mathrm{L}^{-1}$ (3.57 helai) dan pupuk supertonik $3 \mathrm{ml} \mathrm{L}^{-1}+$ chitosan $3 \mathrm{ppm}(3.54$ helai) memberikan hasil yang berbeda nyata dengan pupuk pertumbuhan $1.25 \mathrm{~g} \mathrm{~L}^{-1}+$ chitosan 3 ppm (2.44 helai). Pertambahan jumlah akar berlangsung fluktuatif, peningkatan jumlah akar terjadi mulai dari 0 MSP hingga 8 MSP, sedangkan pada saat 12 MSP jumlah akar relatif berkurang. Hal ini disebabkan adanya akar baru yang muncul serta akar lama yang telah mati akibat membusuk disebabkan media tanam yang kurang terkontrol kelembabannya sehingga secara umum akar lama tersebut menjadi busuk.

Tabel 5. Rata-rata lebar daun planlet anggrek Phalaenopsis selama tahap aklimatisasi

\begin{tabular}{|c|c|c|c|c|}
\hline \multirow{2}{*}{ Perlakuan } & \multicolumn{4}{|c|}{ Umur Planlet (MSP) } \\
\hline & 0 & 4 & 8 & 12 \\
\hline & \multicolumn{4}{|c|}{$\ldots \ldots \ldots \ldots \ldots \ldots \ldots$} \\
\hline \multicolumn{5}{|l|}{ Populasi (P) } \\
\hline TSW-1107 & $1.31 \mathrm{~b}$ & $1.24 \mathrm{~b}$ & $1.27 \mathrm{~b}$ & $1.21 \mathrm{~b}$ \\
\hline TSW-1111 & $1.65 \mathrm{a}$ & $1.56 \mathrm{a}$ & $1.57 \mathrm{a}$ & $1.53 \mathrm{a}$ \\
\hline TSW-1113 & $1.71 \mathrm{a}$ & $1.73 \mathrm{a}$ & $1.62 \mathrm{a}$ & $1.70 \mathrm{a}$ \\
\hline $\operatorname{Pr}>\mathrm{F}$ & $0.0001^{* *}$ & $0.0002^{* *}$ & $0.0005^{* *}$ & $0.0002^{* *}$ \\
\hline \multicolumn{5}{|l|}{ Pupuk Daun (Q) } \\
\hline Supertonik $3 \mathrm{ml} \mathrm{L}^{-1}$ & $1.61 \mathrm{a}$ & 1.64 & 1.58 & $1.63 \mathrm{a}$ \\
\hline Pertumbuhan $1.25 \mathrm{~g} \mathrm{~L}^{-1}$ & $1.67 \mathrm{a}$ & 1.59 & 1.51 & $1.47 \mathrm{ab}$ \\
\hline Supertonik $3 \mathrm{ml} \mathrm{L}^{-1}+$ chitosan $3 \mathrm{ppm}$ & $1.55 \mathrm{ab}$ & 1.38 & 1.51 & $1.53 \mathrm{ab}$ \\
\hline Pertumbuhan $1.25 \mathrm{~g} \mathrm{~L}^{-1}+$ chitosan $3 \mathrm{ppm}$ & $1.38 \mathrm{~b}$ & 1.44 & 1.33 & $1.28 \mathrm{~b}$ \\
\hline $\operatorname{Pr}>\mathrm{F}$ & $0.0361^{*}$ & $0.0985^{\text {tn }}$ & $0.0672^{\text {tn }}$ & $0.0392^{*}$ \\
\hline Interaksi PxQ & $2.70^{*}$ & $2.20^{\operatorname{tn}}$ & $0.84^{\text {tn }}$ & $1.15^{\mathrm{tn}}$ \\
\hline $\mathrm{KK}(\%)$ & 13.11 & 15.97 & 13.48 & 16.47 \\
\hline
\end{tabular}


Tabel 6. Rata-rata jumlah akar planlet anggrek Phalaenopsis selama tahap aklimatisasi

\begin{tabular}{|c|c|c|c|c|}
\hline \multirow{2}{*}{ Perlakuan } & \multicolumn{4}{|c|}{ Umur Planlet (MSP) } \\
\hline & 0 & 4 & 8 & 12 \\
\hline & \multicolumn{4}{|c|}{ Jumlah Akar (Buah) } \\
\hline \multicolumn{5}{|l|}{ Populasi (P) } \\
\hline TSW-1107 & 3.5 & 3.4 & 3.5 & 2.8 \\
\hline TSW-1111 & 3.7 & 3.4 & 3.5 & 2.9 \\
\hline TSW-1113 & 3.7 & 3.7 & 3.8 & 3.5 \\
\hline $\operatorname{Pr}>\mathrm{F}$ & $0.6375^{\mathrm{tn}}$ & $0.4796^{\mathrm{tn}}$ & $0.3120^{\operatorname{tn}}$ & $0.1030^{\operatorname{tn}}$ \\
\hline \multicolumn{5}{|l|}{ Pupuk Daun (Q) } \\
\hline Supertonik $3 \mathrm{ml} \mathrm{L}^{-1}$ & 3.7 & 3.7 & 3.7 & $3.6 \mathrm{a}$ \\
\hline Pertumbuhan $1.25 \mathrm{~g} \mathrm{~L}^{-1}$ & 3.4 & 3.3 & 3.3 & $2.7 \mathrm{ab}$ \\
\hline Supertonik $3 \mathrm{ml} \mathrm{L}^{-1}+$ chitosan $3 \mathrm{ppm}$ & 3.8 & 3.5 & 3.9 & $3.5 \mathrm{a}$ \\
\hline Pertumbuhan $1.25 \mathrm{~g} \mathrm{~L}^{-1}+$ chitosan $3 \mathrm{ppm}$ & 3.5 & 3.5 & 3.5 & $2.4 \mathrm{~b}$ \\
\hline $\operatorname{Pr}>F$ & $0.4642^{\mathrm{tn}}$ & $0.5151^{\mathrm{tn}}$ & $0.2964^{\text {tn }}$ & $0.0199^{*}$ \\
\hline Interaksi PxQ & $0.75^{\mathrm{tn}}$ & $1.22^{\text {tn }}$ & $0.81^{\mathrm{tn}}$ & $1.62^{\text {tn }}$ \\
\hline KK $(\%)$ & 16.92 & 17.01 & 19.67 & 27.86 \\
\hline
\end{tabular}

\section{Panjang Akar}

Pengamatan panjang akar dilakukan sesegera mungkin untuk meminimalkan terjadinya cekaman bagi planlet anggrek yang ditanam. Perlakuan populasi pada umur planlet 0 MSP hingga 8 MSP menunjukkan hasil yang berpengaruh sangat nyata terhadap panjang akar yang diamati.

Tabel 7. Rata-rata panjang akar planlet anggrek Phalaenopsis selama tahap aklimatisasi

\begin{tabular}{|c|c|c|c|c|}
\hline \multirow{2}{*}{ Perlakuan } & \multicolumn{4}{|c|}{ Umur Planlet (MSP) } \\
\hline & 0 & 4 & 8 & 12 \\
\hline & \multicolumn{4}{|c|}{..Panjang Akar $(\mathrm{cm})$} \\
\hline \multicolumn{5}{|l|}{ Populasi (P) } \\
\hline TSW-1107 & $3.47 \mathrm{~b}$ & $3.39 \mathrm{~b}$ & $3.13 b$ & 3.18 \\
\hline TSW-1111 & $4.53 \mathrm{a}$ & $4.42 \mathrm{a}$ & $3.78 \mathrm{a}$ & 3.20 \\
\hline TSW-1113 & $2.79 \mathrm{c}$ & $2.65 \mathrm{c}$ & $2.33 \mathrm{c}$ & 2.54 \\
\hline $\operatorname{Pr}>\mathrm{F}$ & $<.0001^{* *}$ & $<.0001^{* *}$ & $<.0001^{* *}$ & $0.1749^{\text {tn }}$ \\
\hline \multicolumn{5}{|l|}{ Pupuk Daun (Q) } \\
\hline Supertonik $3 \mathrm{ml} \mathrm{L}^{-1}$ & 3.44 & 3.15 & 2.86 & 3.21 \\
\hline Pertumbuhan $1.25 \mathrm{~g} \mathrm{~L}^{-1}$ & 3.84 & 3.82 & 3.34 & 3.02 \\
\hline Supertonik $3 \mathrm{ml} \mathrm{L}^{-1}+$ chitosan $3 \mathrm{ppm}$ & 3.80 & 3.53 & 3.39 & 3.28 \\
\hline Pertumbuhan $1.25 \mathrm{~g} \mathrm{~L}^{-1}+$ chitosan $3 \mathrm{ppm}$ & 3.31 & 3.45 & 2.73 & 2.39 \\
\hline $\operatorname{Pr}>\mathrm{F}$ & $0.1849^{\text {tn }}$ & $0.2674^{\text {tn }}$ & $0.0723^{\mathrm{tn}}$ & $0.1999^{\text {tn }}$ \\
\hline Interaksi PxQ & $1.36^{\mathrm{tn}}$ & $0.74^{\mathrm{tn}}$ & $0.80^{\operatorname{tn}}$ & $0.39^{\mathrm{tn}}$ \\
\hline KK $(\%)$ & 16.53 & 20.08 & 20.10 & 31.52 \\
\hline
\end{tabular}


Populasi TSW-1111 menunjukkan hasil yang berbeda nyata dengan kedua populasi lainnya, begitu pula sebaliknya. Secara berturut-turut panjang akar mulai dari 0 MSP hingga 8 MSP pada populasi TSW-1111 adalah $4.53,4.42$, dan $3.78 \mathrm{~cm}$, sedangkan pada populasi TSW-1107 adalah 3.47, 3.39, dan $3.13 \mathrm{~cm}$ serta pada populasi TSW-1113 adalah 2.79, 2.65, dan $2.33 \mathrm{~cm}$ (Tabel 7). Panjang akar pada populasi TSW-1111 lebih tinggi daripada populasi TSW-1107 dan TSW1113. Panjang akar pada populasi TSW-1113 lebih rendah dibandingkan pada populasi lainnya.

\section{KESIMPULAN}

Karakter morfologi pada populasi yang diamati memiliki nilai koefisien kemiripan yang berbeda. Populasi D015 (Phalaenopsis standar putih $x$ Phalaenopsis standar pink) merupakan populasi yang memiliki keragaman lebih tinggi dengan koefisien kemiripan 59\% dibandingkan populasi lainnya. Percobaan respon pertumbuhan menunjukkan bahwa terdapat interaksi antar perlakuan yang diberikan terhadap jumlah daun yang diamati pada 12 MSP. Pengaruh pupuk supertonik 3 $\mathrm{ml} \mathrm{L}^{-1}$ nyata lebih tinggi dibandingkan pupuk pertumbuhan $1.25 \mathrm{~g} \mathrm{~L}^{-1}+$ chitosan $3 \mathrm{ppm}$ terhadap karakter panjang dan lebar daun, serta jumlah akar pada 12 MSP, populasi TSW-1107 memiliki lebar daun yang lebih rendah dibandingkan populasi lainnya. Populasi TSW-1111 memiliki akar yang lebih panjang dibandingkan populasi lainnya. Persentase tumbuh populasi TSW-1111 lebih tinggi dibandingkan populasi lainnya pada 16 MSP. Konsentrasi pupuk pertumbuhan terlalu tinggi sehingga banyak planlet yang mati pada kedua perlakuan tersebut.

\section{SARAN}

Jumlah individu setiap populasi pada percobaan karakterisasi morfologi perlu ditingkatkan. Konsentrasi pupuk pertumbuhan yang digunakan dapat diturunkan menjadi $0.625 \mathrm{~g} \mathrm{~L}^{-1}$ dengan volume penyemprotan yang dapat lebih mudah terukur serta memperhatikan perhitungan pupuk yang akan digunakan secara ekonomis.

\section{DAFTAR PUSTAKA}

Arditi, J. 1997. Orchid Biology, Reviews, and Perpectives 1. Cornell University Press. Ithaca and London (US).

[BPPT] Balai Pengkajian dan Penerapan Teknologi. 2008. Jurnal Sains dan Teknologi. Balai Pengkajian dan Penerapan Teknologi. Jakarta.

Direktorat Tanaman Hias. 2004. Peningkatan Mutu dan Produktivitas Anggrek Phalaenopsis. Badan Penelitian dan Pengembangan Pertanian, Departemen Pertanian. Jakarta.

Ginting, B., W. Prasetio, T. Sutater. 2001. Pengaruh Cara Pemberian Air, Media, dan Pemupukan terhadap Pertumbuhan Anggrek Dendrobium. BALITHI. Jakarta.

Gomez, K.A., A.A. Gomes. 1995. Prosedur Statistika untuk Penelitian Pertanian. Ed ke-2. Sjamsuddin E, Baharsjah JS, penerjemah. UI Pr. Terjemahan dari: Statistical Procedure for Agriculture Research. HIm 7-86. Jakarta.

Hardjowigeno, S. 2007. Ilmu Tanah. Akademika Pressindo. Jakarta.

Iswanto, H. 2005. Petunjuk Praktis Merawat Anggrek. Agro Media Pustaka. Depok.

Kartikasari, R. 2009. Pengaruh perbedaan media tanam terhadap keberhasilan aklimatisasi Phalaenopsis sp. Skripsi. Universitas Negeri Malang. Malang.

Rohlf, F.J. 1998. NTSYSpc: Numerical Taxonomy and Multivariate Analysis System Version 2.02. Exeter Publications. New York.

Surtinah, E. Mutryarny. 2013. Frekuensi pemberian grow quick $\mathrm{lb}$ terhadap pertumbuhan bibit anggrek Dendrobium pada stadia komunitas pot. J. Ilmiah Pertanian. 10(2): 35-36.

Suryati, Y. 2007. Respon tanaman anggrek bulan terhadap jenis media tanam dan letak tanaman pada sistem pertanian 
organik secara vertikultur. Prosiding Seminar Nasional Hasil Penelitian yang Dibiayai oleh Hibah Kompetitif; 2007 Ags 1-2; Bogor, Indonesia. Fakultas Pertanian Universitas Muhammadiyah. 128. Jakarta.

Suwandi, F. Chan. 1982. Pemupukan pada Tanaman Kelapa Sawit yang Telah Menghasilkan dalam Budidaya Kelapa Sawit (Elaeis guineensis Jacq.) oleh Lubis AU, Jamin A, Wahyuni S, Harahap IR. Pusat Penelitian Marihat Pematang Siantar. Hlm 191-210. Medan.

Syukur, M., S. Sujiprihati, R. Yunianti. 2012. Teknik Pemuliaan Tanaman. Penebar Swadaya. Jakarta.
Wiyono, S. 2007. Perubahan iklim dan ledakan hama penyakit tanaman. http://www.rimbawan.zcom/APHI0611/ KUMPULAN_TULISAN/2007/juli_20 07/Seminar28Juni2007/Perubahan\%20I klim_Ledakan\%20hama\%20dan\%20pe nyakit\%20tanaman.pdf. [30 Mei 2014].

Yosepa, T., C. Siregar, E. Gusmayanti. 2012. Pengaruh penggunaan jenis media terhadap aklimatisasi anggrek Dendrobium sp. (hibrida). J. Sains Mahasiswa Pertanian. 2(2): 1-2.

Zhao, Y. 2005. Chitosan Coating and Its Application in Fruits and Vegetables Department of Food Science \& Technology. Oregon State University. Oregon (US). 